\title{
The risk of developing repetitive stress injury in seamstresses, in the clothing industry, under the perspective of ergonomic work analysis: a case study
}

\author{
Melo Junior, A. S. \\ Superintendência Regional do Trabalho na Paraíba, Ministério do Trabalho e Emprego, Praça Venâncio Neiva, \\ 11, Centro, 58010-011, João Pessoa, Paraíba, Brasil, Phone:55 8393420596
}

\begin{abstract}
This study presents the sewing task with the approach of the ergonomic analysis of the work, in the seam activity in a clothing industry to identify the relationship between the use of different sewing machines and the activity of sewing pants and blouses, which brings larger risk for the development of work related musculoskeletal disorders. It was done a study of transverse and exploratory cut, in that was used a methodology control of multiple analysis of variables. The population objective was the workers that exercise the activity in the section of makings, with 93 workers, being $54,8 \%$ sewing auxiliary and $45,2 \%$ dressmakers. Most is single $(75,3 \%)$, has the 2 nd complete degree $(58,0 \%)$ and the medium age was 25 years old. As results were observed that the machines serger, zig zag and traveti are classified as of high risk of developing work related to musculoskeletal disorders, that the postures assumed during the execution of the tasks were classified as bad or terrible, and that the workstations were just classified as reasonable. It was concluded then, that a relationship exists among the task of sewing pants and blouses, and the risk of the development of work related to musculoskeletal disorders.
\end{abstract}

Keywords: repetitive stress injury, seamstresses, clothing industry, ergonomic work analysis

\section{Introduction}

With the advent of the new model of flexible production clothing industries, from the 80 's, a new rhythm of work was imposed seeking productivity and product quality. There was thus an increasingly tense labor, generating uncertainty and promoting the emergence of new diseases. Technological developments and new management approaches are important issues for ergonomic research in this new millennium.

Under this approach the working conditions offered to workers they have generated in many companies, physical and mental discomfort, and consequently the increase of various illnesses, among them the work-related musculoskeletal disorders (MSDs), which currently are also related modernization. The consequences of increasing the number of cases of MSDs have been the source of many of the concerns of business organizations, in addition, are causes of physical and psychological suffering for the workers.

For organizations are direct consequences, as with the removal of the operators of jobs by injuries, has reduced productivity, increased absenteeism, increased the final cost of the product, the company's negative image in society, the expected delay in delivery of products and an uncomfortable environment in the sector of work, because these lesions makes removal by a climate of doubt and anxiety among operators, which directly reflects the other $[13\}$.

The main causes of MSDs are the biomechanical factors and organizational work, which can be categorized into four groups, namely: (1) strength, (2) poor posture of the upper limbs, (3) repeatability, and (4) vibration and mechanical compression. They are part of the groups most likely to have symptoms and develop this disease, workers whose functions have 
limited variations of movement, held in high frequency and with the use of force.

\section{1- The seamstress activity}

The workplace clothing industries can expose workers to unfavorable environmental conditions due to the presence of physical hazards, ergonomic and mechanical, can compromise the health of workers. The tasks carried out as a seamstress in the activity are usually in a seated position for most of the working day, and there are other factors that contribute to the development of these diseases such as repetitive motion, awkward postures and force requirement. The stance taken by these professionals and the intensity of the work day, provide discomfort and pain, which can generate future pathologies in the neck, back and upper limbs [2, 13].

The seamstresses are responsible for organizing the workplace, preparing sewing machines and sewing clothes for finishing. Also, prepare parts for sewing and embroidery, according to the templates, sew and embroider pieces made accessories, and check the quality of sewing and finishing of apparel pieces.

For the development of the task of sewing, many manual tasks are performed and these require a visual accompaniment to the inherent requirement of the task, this means that the torso and head are inclined forward (Figure 1 - Activity seamstress). The neck and the back is subjected to strains maintained for long periods, which may cause pain, as well as the back, which is also subjected to stress, when it is necessary to rotate the body while the worker on a fixed seat.

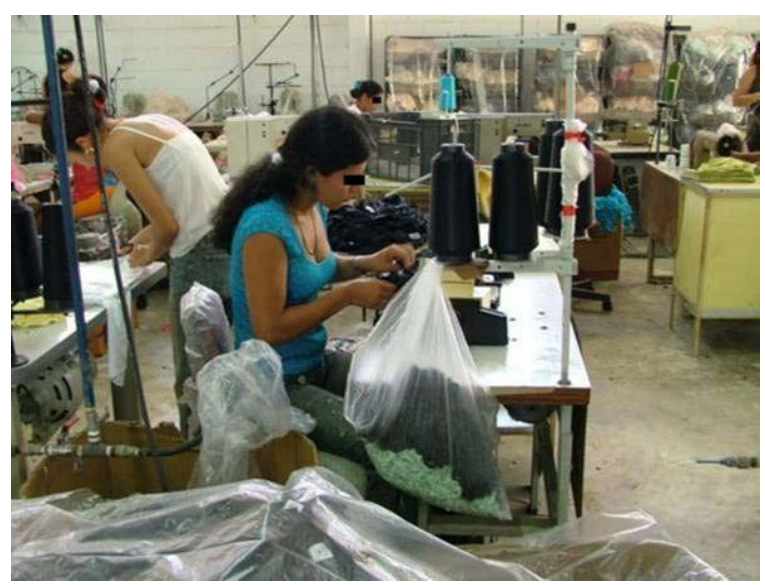

Figure 1 - Activity seamstress
Specifically in the case of working with sewing machines, studies have shown that inadequacies in the design of their operators exposed to various constraints, such as awkward postures and repetitive movements of limbs [5, 6, 13].

In this activity, it is emphasized that the work in the clothing industry involves monotonous, highly repetitive tasks performed in a sitting posture with the upper back curved and the head directed to the sewing machine [9].

\section{2- The garment industry}

The clothing industry is one of the most widespread industries in the world and is an important source of income generation and employment for many countries, especially in developing countries (Figure 2 - Industrial shed). It is common that the beginnings of industrialization of a country to be confused with the installation and development of the textile and clothing $[11,13]$.

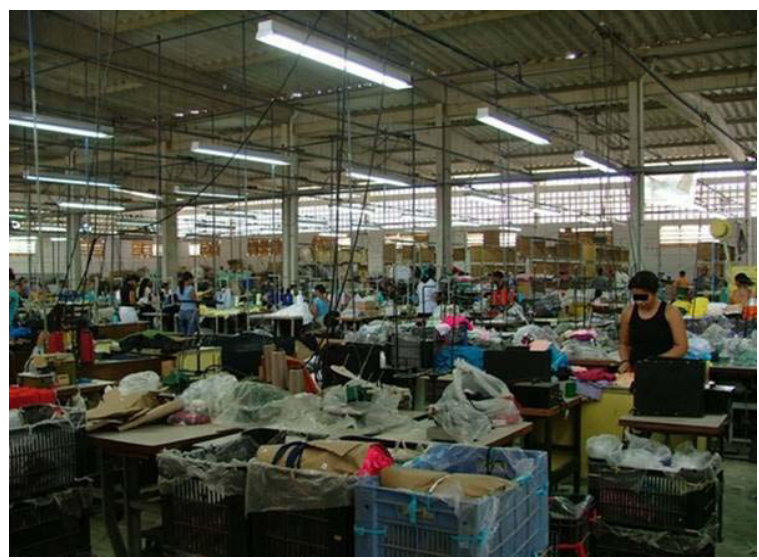

Figure 2 -Industrial shed

This type of industry is defined as the set of companies that make the fabric or mesh, (Figure 3 - View of the knitting industry (Circular Loom)), made from natural fibers and manufactured in pieces of clothing (women's, men and children), home (bed and bath); decoration (curtains and awnings) or packaging, among others, besides having a wide variety of raw material used, which provide a considerable workload, which holds, among other characteristics, incorrect postures, repetitive movements, absence of periods for recovery from fatigue, pressure for results, stress and overtime $[8,13]$. 


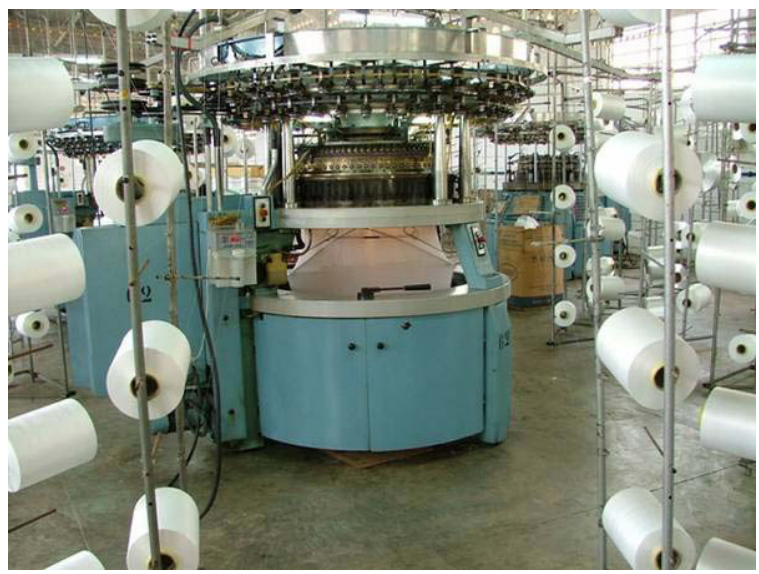

Figure 3 -View of the knitting industry (Circular Loom)

The clothing industry of garments and trims has significant importance in the economy and world trade in manufactures. With sales of Textile and Apparel Chain of about $\$ 52$ billion (in 2009 was recorded sales of $\$ 47$ billion) [1].

According to the Brazilian Association of Textile and Clothing - ABIT, Brazil is listed in the 2010 Textile, report the Brazilian textile industry sector on the internal market in 2009, and prepared by the Institute of Industrial Studies and Marketing - IEMI, the textile industry and clothing continues to be one of the most employed in Brazil, with 1.6 million workers, or about $17 \%$ of jobs generated by the manufacturing industry [1].

Among the information that impress in the report, is the participation of the Brazilian textile chain manufacturing industry, with $5.7 \%$ of revenues. In terms of workforce, their participation was even more significant, ie $17.1 \%$ of total employment in processing industry [1].

Since the data on number of companies and jobs generated, IEMI points out that between 2005 and 2009 , the number of companies active in the textile segment grew $16 \%$, while the segments of manufacturing growth was $22 \%$. The employed persons, an increase of $3.9 \%$ in the segments of textiles and clothing $8.7 \%$ in [1].

According to that report, the average production of manufacturing was 9.8 billion pieces, employing 1.7 million employees, of which $75 \%$ is labor, female labor, and is considered the $2 \mathrm{nd}$. largest employer in the manufacturing industry in Brazil and 2. largest generator of the first job. Represents $13.15 \%$ of jobs in manufacturing industry and about $3.5 \%$ of total
GDP of Brazil, with about 30000 companies and is the fifth largest textile producer in the world [1].

\section{3- The risk of MSDs}

The intensive use of manpower, which is characteristic of this type of business, generating enough qualified reliance on the human factor, those factors that lead workers to stay in positions orthostatic / static, performing repetitive movements for long periods of time and in unfavorable environmental conditions causing varying degrees of physical and mental fatigue and contributing to the emergence of occupational diseases, especially the group MSDs.

For operators affected by these injuries have been beyond the physical suffering, mental suffering, professional and family maladjustment. In most cases, the removal eliminates the possibility of a promotion, and therefore reduces the prospects for professional growth of the operator. It is even more critical when the situation involves partial loss of ability to work or even complete when the operator is at the height of their productivity and professional experience, since the incidence is in the range of 20 to 39 years $[2,13$, $15,16]$.

The tasks of the seamstresses are performed in a seated position for approximately $83.31 \%$ of the working day, the rhythm of production and organization do not allow extra breaks and changes of posture sitting to standing posture $[12,13]$.

It is also emphasized that the activity of sewing can be considered static action, with highly repetitive movements, noting that the activity of sewing is great demand for use of visual acuity and fine motor, with high repeatability of movements.

It is observed that the segment is characterized by large made varieties of raw material, providing high heterogeneity of products. Such heterogeneity triggers the creation of diversified products. This great variability of its production provides varying degrees of exposure to risk factors of diseases of the cervical, dorsal and upper limbs, as the piece that is being manufactured $[12,13,17]$.

\section{4-Accidents at work in Brazil}

The statistics of occupational accidents in Brazil occurred in the last 41 years reveal a tragic fact and at the same time worrying on the condition that the country was in the 70's world champion of occupational accidents. 
According to the National Institute of Social Security (INSS), between the years 2007 and 2009 was recorded by Social Security in a total of $2,138,955$ work-related injuries, and $60,642(2.84 \%$ of total accidents) in groups 13 and 14 of the National Classification Economic Activities - CNAE on the textile industry and clothing where the typical accidents accounted for $54.69 \%$ of total accidents and occupational diseases $2.47 \%$ [3].

\section{Method}

We used a systematic observation of jobs and the use of questionnaires and checklists aimed to study the problem. We conducted a cross-sectional study and exploration in a methodology that was used for multivariate analysis and control variables.

The target population was workers engaged in the activity in the garment sector, with a sample of 93 workers, and $54.8 \%$ auxiliary seamstresses sewing and $45.2 \%$. Most are single (75.3\%), has two high school graduates $(58.0 \%)$ and average age of 25 years.

The study as independent variables: function, sex, age, length of service with the company, depending on length of service and type of machine used to perform the task and dependent variables: the condition of an ergonomic work station; risk of tenosynovitis and injuries, pain perception, attitudes at work, time in seconds of the task.

As instruments for data collection, we used the following checklist:

A- Checklist for Evaluating Coarse General on the Status of an Ergonomic Workstation adapted from Couto [4].

Aims at a systematic evaluation of ergonomic conditions of a job through observation and completion of the checklist.

A suffered adaptation to their suitability in this activity with a view does not exist in the literature for this method, in the garment industry.

It has great practical value because it allows their application as screening, and facilitate the identification of the area to improve working conditions.

B- Checklist for Risk Assessment Simplified Tenosynovitis and Cumulative Trauma Injury Upper Limb adapted from Couto [4].

Instrument built to systematize a simplified assessment of the risks of injury to upper limbs through observation and completion of the checklist.

Changes were made to fit this study, goal setting, because there is no literature on the application of this method in the garment industry.

It has great practical value, allowing the identification of the area to improve working conditions.

C- Checklist for Observations of working postures adapted from Fialho and Santos [7].

Conceived to identify the positions taken by the employee during the task with respect to the back seats of work, position of the legs, position of the femur, position of the trunk, spine curvature, slope of the bust, head position and seat position.

We made some adjustments to their suitability in this activity, goal setting, with a view there in the literature, the application of this method in the garment industry.

The criteria for interpretation to identify the correct posture Yes for the item searched in the same way that identifies No poor posture.

As for the procedures, we used a standard procedure, in which the applicators were previously trained and instructed to intervene as little as possible on the answers given by participants, thus minimizing the possibility of response bias.

Questionnaires were administered individually, participants simply follow the directions given by the interviewer. At first, participants were presented to the Term of Consent, explaining the objectives of the study and inviting them to participate.

Was granted the voluntary nature of participation and respect for ethical guidelines governing research with human beings, according to the terms of Resolution 196/96 of the National Health

For statistical analysis we used the statistical software SPSS for Windows version 15.0. We used descriptive statistical analysis and decision making: frequency, percentage, mean and standard deviation, chi-square $(\chi 2)$ to check for statistically significant differences between observed and expected frequencies in contingency tables of categorical variables, $t$ test Student (compare mean values of two groups), analysis of variance (ANOVA) to compare mean values of three or more groups - to identify where the differences were statistically significant, we used the Scheffé post hoc test. 


\section{Results}

Regarding the distribution of work performed there was the identification of all the tasks performed, nine in all, where the task is performed over the closing of parts with $31(33.3 \%)$ jobs involved, then the task of sheath placement, with $21(22.6 \%)$ jobs are taken, these tasks together make up the vast majority of the activities performed in the garment sector and account for $52(55.9 \%)$ held jobs.

The distribution of type of machine used shows that the machine is the most used serger with 51 $(54.8 \%)$ followed by jobs coverstitch sewing machines with $21(22.6 \%)$ in activity.

The distribution of the type of piece produced as part type has produced over the blouse with 56 $(60.2 \%)$ held jobs in the production of this piece.

To check the differences between the mean values of Workstation, Risk of MSDs and Posture at work, we used the $\mathrm{t}$ test where there was no statistically significant difference $(t=1.96, p=0.05)$ only the comparison of mean values between the samples and sew blouse and panties variable Workstation, as evidenced in Table 1 - Differences in the mean values.

In this respect, based on the results presented, we could say that the condition Ergonomic Workstation is a reasonable condition, both with regard to sew blouse and panties.

Table 1

Differences in the mean values

\begin{tabular}{|c|c|c|c|}
\hline Workstation & Average & Standard deviation & $t$ of student \\
\hline Blouse & 5,55 & 0,98 & \multirow{2}{*}{1,$96 ; p=0,05$} \\
\hline Panties & 5,86 & 0,53 & \\
\hline $\begin{array}{l}\text { Risk of } \\
\text { MSDs }\end{array}$ & Average & Standard deviation & $t$ of student \\
\hline Blouse & 15,13 & 1,95 & \multirow{2}{*}{$\begin{array}{l}1,37 ; p= \\
0,18\end{array}$} \\
\hline Panties & 14,59 & 1,72 & \\
\hline $\begin{array}{l}\text { Postures at } \\
\text { work }\end{array}$ & Average & Standard deviation & $t$ of student \\
\hline Blouse & 3,57 & 1,47 & \multirow{2}{*}{0,$85 ; p=0,36$} \\
\hline Panties & 3,24 & 2,01 & \\
\hline
\end{tabular}

Regarding differences between the average values of the job depending on the type of machine used, it was observed that there is no statistically significant differences $[\mathrm{F}(3.89)=2.95, \mathrm{~ns}]$ between the mean values of the variable Workstation according to the types of machines used, as evidenced in Table 2 -
Differences between mean values of the job depending on the type of machine used.

In any case it was found that the overall average of $5.69(\mathrm{SD}=0.84)$, so one can then infer that the variable Workstation has a reasonable valuation point of view the average.

Table 2

Differences between mean values of the job depending on the type of machine used.

\begin{tabular}{|l|l|l|l|}
\hline Workstation & Average & $\begin{array}{l}\text { Standard } \\
\text { deviation }\end{array}$ & F Ratio \\
\hline Serger & 5,57 & 1,00 & \multirow{2}{*}{$\mathrm{F}(3,89)=2,95 ;$} \\
$p=0,06$.
\end{tabular}

As for the variable risk of MSDs in the type of machine used, as evidenced in Table 3 - Differences between mean values of the risk of MSDs in the type of machine used, it was observed that no statistically significant differences $[\mathrm{F}(3,89)=7.35, p=0.000]$ between the mean values, with proven application of Sheffer's post hoc test identifying, among the machines studied, coverstitch sewing machines that has the highest average that is of $16.29(\mathrm{SD}=1.55)$ and differs in relation to zig zag and serger machines, for not sharing the same envelope, and there is no difference between the mean values of the machine traveti compared to other machines

As the reading of averages, we could say that the machine coverstitch sewing machines presents a moderate risk for developing MSDs, which recommends the improvement of the workplace, and other machines are classified as high risk of developing MSDs, requiring restructuring the job.

Table 3

Differences between mean values of the risk of MSDs in the

\begin{tabular}{|c|c|c|c|}
\hline Risk of MSDs & Average & $\begin{array}{l}\text { Standard } \\
\text { deviation }\end{array}$ & F Ratio \\
\hline Serger & $14,75_{\mathrm{a}}$ & 1,88 & \multirow{4}{*}{$\begin{array}{l}\mathrm{F}(3,89)=7,35 \\
p=0,000\end{array}$} \\
\hline Traveti & $14,50_{\mathrm{ab}}$ & 1,41 & \\
\hline $\begin{array}{l}\text { Coverstitch } \\
\text { sewing machines }\end{array}$ & $16,29 \mathrm{~b}$ & 1,55 & \\
\hline Zig Zag & $13,62_{a}$ & 1,26 & \\
\hline Total & 14,91 & 1,87 & \\
\hline
\end{tabular}

Note: $\mathrm{F}(3.89)=7.35, \mathrm{p}=0.000$. Mean values not sharing the same subscript have a statistically significant difference post hoc test Sheffé. 
With respect to the variable posture depending on the type of machine used, as shown in Table 4 - Difference between the mean position depending on the type of machine used was observed that there is statistically significant $[\mathrm{F}(3.89)=6,36, p=0.001]$ between the mean values of the machine zig zag, in relation to machines and serger traveti the one that has the highest average score (mean $=4.25, \mathrm{SD}=$ $1.20)$ as there is no significant differences between mean values of the machine coverstitch sewing machines compared to other machines. These differences were shown by post hoc Scheffé test.

Table 4

Difference between the mean position depending on the type

\begin{tabular}{|c|c|c|c|}
\hline Posture at work & Average & $\begin{array}{l}\text { Standard } \\
\text { deviation }\end{array}$ & F Ratio \\
\hline Serger & $3,86_{a}$ & 1,58 & \multirow{4}{*}{$\begin{array}{l}\mathrm{F}(3,89)=6,36 \\
p=0,001\end{array}$} \\
\hline Traveti & $4,25_{\mathrm{a}}$ & 2,37 & \\
\hline $\begin{array}{l}\text { Coverstitch } \\
\text { sewing machines }\end{array}$ & $3,05_{\mathrm{ab}}$ & 1,20 & \\
\hline Zig Zag & $1,92_{b}$ & 1,49 & \\
\hline Total & 3,44 & 1,71 & \\
\hline
\end{tabular}

Note: $\mathrm{F}(3.89)=6.36, \mathrm{p}=0.001$. Mean values not sharing the same subscript have a statistically significant difference post hoc test Sheffé.

In this respect, it was observed that the average obtained by the machine zig zag in relation to posture, it was classified as poor, in which recommended the restoration of the job (Figure $4-$ View of the machine zig zag). The other machines fit the very poor risk, which recommended the reformulation of the job.

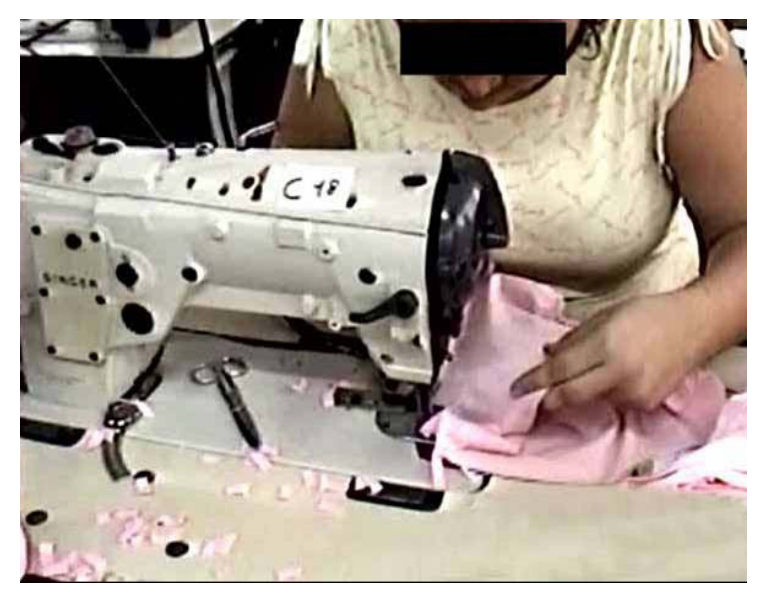

Figure 4 - View of the machine zig zag.
It was observed that the machines serger, zig zag and traveti are classified as high risk of developing msds, the postures assumed during the execution of the tasks were classified as poor or very poor, and that the jobs were classified only as reasonable. The most common task performed is the closure of parts $(33.3 \%)$, the machine is the most used serger (54.8\%), and most produced type of piece is the blouse $(60.2 \%)$.

\section{Discussion}

The development of MSDs is based primarily on the existence of certain factors, which combined produce various levels of discomfort and limitations in the lower limbs. Among these factors, could be highlighted as follows: task time, repetition of movements, posture and lack of rest, as noted in the study. In the study, noted that there is a combination of some of these factors with a high repetition of movements, posture, and fixed in chairs that are not suitable for the job, and a lack of definition of periods of breaks during the day work.

These results were found when they examined the activity of sewing panties, and noticed that most of the cycle time for completion of tasks has a time less than 30 seconds per piece sewn, featuring a repetitiveness that prevents the muscles of the upper limb responsible for executing the task, to recover, causing a musculoskeletal overload, arising as a consequence, more likely to develop MSDs.

The highlight came in the activity of sewing blouses, where most often in the production of these parts $(60.2 \%)$, the duration of execution cycles with a task longer than 30 seconds to the same conclusion, that these cycles play many operations, each requiring one or more types of movements that are repeated. If these operations ordering muscle movements similar anatomical structures are the same overloaded.

The worsening of the factors takes place, because, except for the machine coverstitch sewing machines, other machines showed a statistically significant difference in the risk of developing MSDs, and are classified as high risk, with positions taken during the execution of the tasks classified as poor or very poor, in addition to the jobs being rated as only fair. 


\section{Conclusion}

It was concluded then that there is, in setting studied, a relationship between the task of sewing pants and blouses, and the risk of developing MSDs, with a view that the presence of triggering factors of this nosologic entity carries considerable risk to the health of workers exposed in the way work is currently running.

It was recommended the introduction of breaks during the workday; suitability of jobs due to the different heights between the workers, development of work instruction-oriented approach in the operation of sewing machines, and the adoption of production management system with the planning and production control.

\section{References}

[1] ABIT. (2010). Relatório Setorial da Indústria Têxtil Brasileira 2010. Available on: <http://www.abit.org.br/site/ navegacao.asp?id menu $=1 \&$ id $\_$sub $=4 \&$ idioma $=$ PT $>$. Acess in: January 18, 2011.

[2] Ávila, C. A. V.; Santos, L. F. (2000). Estudo dos distúrbios osteomusculoligamentares relacionados ao trabalho (dort) em costureiras da indústria têxtil sulfabril. In.: CONGRESSO BRASILEIRO DE ERGONOMIA, 10, 2000. Rio de Janeiro: Anais... Rio de Janeiro. CD-rom.

[3] BRASIL.(2010). Ministério da Previdência Social, Instituto Nacional do Seguro Social, Anuário Estatístico da Previdência Social 2009. Brasília: MPS, INSS, Available on: $<$ http://www.mpas.gov.br/conteudoDinamico.php?id=990. Acess in: January 182011.

[4] Couto, H. A.(1995). Ergonomia aplicada ao trabalho: Manual técnico da máquina humana. Belo Horizonte: Ergo, 1995. v. 1.

[5] Dellerman, N. J.; Dul, J. (2002).Sewing machine operation: workstation adjustment, working posture, and workers' perceptions. International Journal of Industrial Ergonomics, v. 30, p. 341-353.

[6] Estivalet, P. S. et al. (2004). Avaliação ergonômica de máquina de costura. In.: ENCONTRO NACIONAL DE ENGENHARIA DE PRODUÇÃO, 24, 2004. Florianópolis: Anais... Florianópolis. Florianópolis. CD-rom.

[7] Fialho, F; Santos N. (1997). Manual de análise ergonômica no trabalho. 2 ed. Curitiba: Gênesis Editora, 1997. 283 p.
[8] Gomes , M. L. B. (2002). Um modelo de nivelamento da produção à demanda para a indústria de confecção do vestuário segundo os novos paradigmas da melhoria dos fluxos de processos. João Pessoa: UFPB, 2002. 320 p. Tese (Doutorado em Engenharia de Produção) Programa de Pósgraduação em Engenharia de Produção, Universidade Federal de Santa Catarina, 2002.

[9] Kaergaard, A; Andersen, JH. (2000). Musculoskeletal disorders of the neck and shoulders in female sewing machine operators: prevalence, incidence and prognosis. Occup Environ Med. Aug; v.57, ano 8. n.5, p.28-34 Aug,

[10] Li, G.; Halslesgrave, C. M.; Corlett, E. N. (1995). Factors affecting posture for machine sewing tasks: The need for changes in sewing machine design. Applied Ergonomics, v. 26, n. 1 , p. $35-46$

[11] Lupatine, M. P.(2004). As transformações produtivas na indústria têxtil-vestuário e seus impactos sobre a distribuição territorial da produção e a divisão do trabalho industrial. Campinas, 2004, 152 p. Dissertação (Mestrado em Política Científica e Tecnológica) Universidade Estadual de Campinas, Instituto de Geociências. 2004.

[12] Marques, M. N. M.; Siqueira, A. R. (2000). Análise ergonômica do posto de trabalho das costureiras em indústria de confecção infantil. In.: CONGRESSO BRASILEIRO DE ERGONOMIA, 10, 2000. Rio de Janeiro: Anais... Rio de Janeiro, 2000. CD-rom.

[13] Melo Junior, A. S. (2007). A Tarefa de costurar sob a ótica da análise ergonômica do trabalho: $\mathrm{O}$ risco do desenvolvimento de LER/DORT. 136 p. Dissertação (Mestrado em Engenharia de Produção) - Programa de Pós-graduação em Engenharia de Produção, Centro de Tecnologia, Universidade Federal da Paraíba. 2007

[14] Nag A; Desai H; Nag K. (1992). Work stress of women in sewing machine operation. J HUMAN ERGOL. n.21, p.47-55.

[15] Oliveira, C. R. et al. (1998). Manual prático de LER. 2. ed. Belo Horizonte: Heath, 1998.

[16] Queiroz, M. F. F; Ambrosi, D. (2004). Compreendendo o trabalho da costureira: um enfoque para a postura sentada. In.: CONGRESSO BRASILEIRO DE ERGONOMIA, 13, Fortaleza: 2004. Anais... Fortaleza. CD-rom.

[17] Silva, A. (2002). A organização do trabalho na indústria do vestuário: uma proposta para o setor da costura. Florianópolis. 141 p. Dissertação (Mestrado em Engenharia de Produção) Programa de Pós-Graduação em Engenharia de Produção, Universidade Federal de Santa Catarina, Florianópolis. 